\title{
Parathyroid hormone assay in clinical decision-making
}

\author{
SOLOMON POSEN, MICHAEL KLEEREKOPER, JOAN P INGHAM, JANICE E HIRSHORN
}

British Medical fournal, 1975, 1, 16-19

\section{Introduction}

With the increasing availability of parathyroid hormone (PTH) assays $^{1-7}$ the clinician must ask himself what decisions, if any, he is likely to base on the results of this investigation. What surgical operations will be performed or deferred? What treatment will be given or withheld because of a particular PTH concentration? We attempt here to answer these questions by analysing several clinical conditions and individual case reports. Whenever results of PTH estimations are quoted they have been obtained by the method of Kleerekoper et $a l^{7}$, which, though not as sensitive as some other methods, has the advantage of using commercially available reagents. The antibody used "sees" both the intact PTH molecule and C-terminal fragments. The clinical conclusions are valid for most other diagnostic assays.

\section{Urinary stone formers}

\section{HYPERCALCAEMIC PATIENTS}

Four per cent of unselected patients with urinary calculi are hypercalcaemic. ${ }^{8}$ Most such patients have detectable PTH levels, ${ }^{7}$ and are thus candidates for neck exploration. In these circumstances PTH assay has considerably enhanced the level of diagnostic sophistication and it has simplified the flow-chart pattern for clinical decisions (fig 1). Because of the relative rarity of patients with primary hyperparathyroidism who do not have detectable immunoassayable PTH (table I) we have become reluctant to recommend neck exploration in such patients, especially if their bone biopsies show no evidence of parathyroid osteopathy.

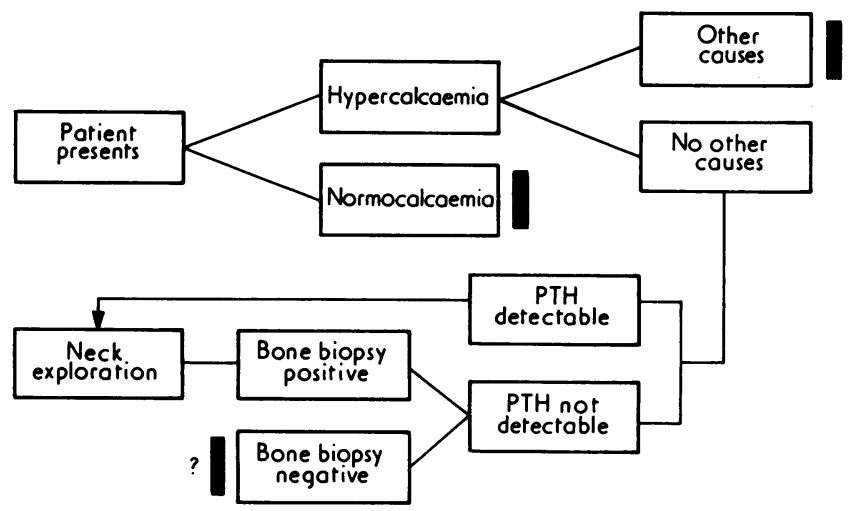

FIG 1-Investigation flow chart in patients suspected of suffering from primary hyperparathyroidism. In presence of hypercalcaemia any detectable PTH is considered abnormal and, provided the patient has no obvious features of malignancy, he becomes a candidate for neck exploration.

\section{NORMOCALCAEMIC PATIENTS}

Most patients with urinary calculi are normocalcaemic. ${ }^{8}$ About

\footnotetext{
Department of Medicine, Sydney Hospital, Sydney, New South Wales

SOLOMON POSEN, MD, FRACP, associate professor of medicine MICHAEL KLEEREKOPER, BSC, MB, research fellow

JOAN P INGHAM, MRCP, FRACP, research fellow

JANICE E HIRSHORN, BSC, research fellow
}

$25 \%$ of such patients in "developed" countries ${ }^{8}{ }^{9}$ have hypercalciuria while the remainder have no demonstrable abnormality of calcium metabolism. We have found serum immunoreactive PTH in normocalcaemic stone formers (whether hypercalciuric or normocalciuric) to be no higher than in normal subjects (fig 2). This finding is similar to that of Pak et al, ${ }^{10}$ though Coe $e t$ al ${ }^{11}$ found raised levels in idiopathic hypercalciuria. Normal or undetectable PTH levels in such individuals have reinforced our current policy not to recommend neck exploration in normocalcaemic stone formers even if urged by desperate patients or urologists to "do something."

TABLE I-Immunoassayable PTH in 87 hypercalcaemic patients submitted to neck exploration for suspected primary hyperparathyroidism

\begin{tabular}{|c|c|c|}
\hline $\begin{array}{l}\text { Immunoreactive } \\
\text { PTH in peripheral } \\
\text { blood }\end{array}$ & $\begin{array}{l}\text { No of patients with } \\
\text { abnormal parathyroid } \\
\text { tissue }\end{array}$ & $\begin{array}{l}\text { No of patients with } \\
\text { no abnormal parathyroid } \\
\text { tissue }\end{array}$ \\
\hline $\begin{array}{l}\text { Raised* } \\
\text { Non-parallel† } \\
\text { Not detected }\end{array}$ & $\begin{array}{r}75 \\
1 \\
4\end{array}$ & $\begin{array}{l}\mathbf{4} \\
\mathbf{0} \\
\mathbf{3}\end{array}$ \\
\hline Total & 80 & 7 \\
\hline
\end{tabular}

*Any detectable immunoreactive PTH in peripheral blood is considered raised in

hypercalcaemic patients. at different dilutions.

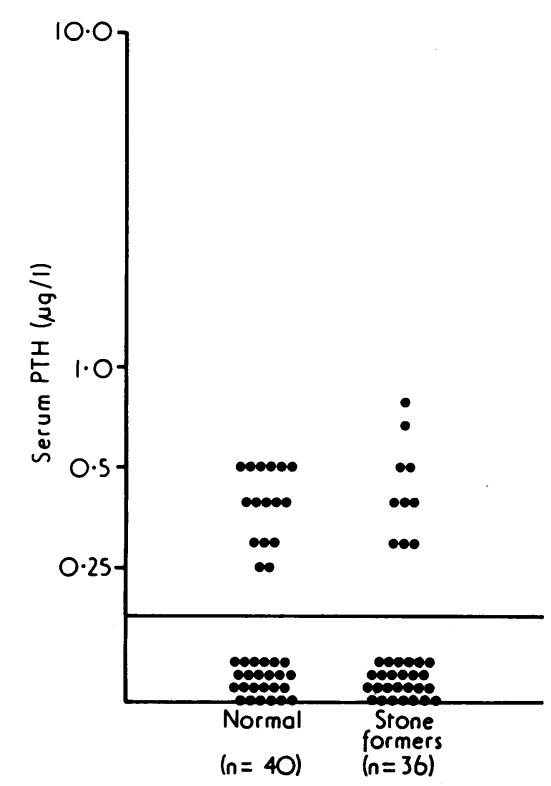

FIG 2-Serum immunoreactive PTH in normal subjects and normocalcaemic stone formers. Such patients, whether normocalciuric or hypercalciuric have serum immunoreactive PTH levels that are indistinguishable from those of normal subjects. Line indicates limit of detectability.

\section{Hypercalcaemia discovered during routine screening}

With the increasing use of multiphasic screening of well or sick people, every hospital is discovering relatively large numbers of hypercalcaemic subjects. Among the ambulant patients described by Boonstra and Jackson ${ }^{12}$ the commonest identifiable cause of hypercalcaemia was hyperparathyroidism. McClellan et $a l,{ }^{13}$ who investigated a group of inpatients, found hyperparathyroidism to be the second commonest identifiable cause of hypercalcaemia.

There are many other causes of hypercalcaemia which medical students and candidates for higher degrees are expected to memorise. As a rule conditions such as hyperthyroidism, malignancy, vitamin D intoxication, or Addisonism do not give rise to diagnostic difficulties 
when associated with hypercalcaemia. The clinician recommending neck exploration in a patient with unexplained hypercalcaemia, however, is constantly facing the question whether "non-hyperparathyroid" causes of hypercalcaemia have been adequately excluded. The following case report shows how PTH estimations may help to arrive at a decision.

Case 1-A 32-year-old housewife, who had been a heavy ${ }^{14}$ consumer of analgesic preparations, presented because of weight loss and recurrent abdominal pain of six months duration. Physical examination showed a blood pressure of $150 / 100 \mathrm{~mm} \mathrm{Hg}$ and diffuse abdominal tenderness. The serum creatinine was $203 \mu \mathrm{mol} / 1(2.3 \mathrm{mg} / 100 \mathrm{ml})$ while the serum calcium was $3.13 \mathrm{mmol} / \mathrm{l}(12.5 \mathrm{mg} / 100 \mathrm{ml})$. All other biochemical as well as numerous radiological and haematological studies gave normal results. Serum immunoreactive $\mathrm{PTH}$ was not detected in three specimens taken on separate days over two weeks. In view of this finding neck exploration was deferred. Hypercalcaemia was noted for another six weeks, but at the end of a further six weeks ( 14 weeks after the original presentation) the patient was found to be normocalcaemic. Normocalcaemia persisted during the subsequent 12 months without further deterioration of renal function.

Comment-While this patient at no stage admitted taking calciumcontaining medications or vitamin $\mathrm{D}$, it seems likely in retrospect that she suffered from vitamin $\mathrm{D}$ intoxication or the milk alkali syndrome. The absence of detectable immunoreactive $\mathrm{PTH}$ protected this patient from an unnecessary neck exploration.

\section{Hypercalcaemia of Malignancy}

The association between malignant neoplasms and hypercalcaemia has long been known. ${ }^{1516}$ Malignancies of various types collectively constitute the commonest single cause of hypercalcaemia among hospital inpatients, ${ }^{13}$ while about $10 \%$ of unselected patients with cancer are hypercalcaemic at some stage of their illness. ${ }^{15} 17$ Single serum calcium determinations performed on admission to hospital in 165 patients with suspected malignancies subsequently proved histologically showed that 152 patients had levels of $2.68 \mathrm{mmol} / 1$ $(10.7 \mathrm{mg} / 100 \mathrm{ml}$ ) or less (normal $2.45 \pm 0.1 \mathrm{mmol} / 1(9.8 \pm 0.4 \mathrm{mg} /$ $100 \mathrm{ml}))$. Six had levels of $2 \cdot 70-2 \cdot 88 \mathrm{mmol} / 1(10 \cdot 8-11 \cdot 5 \mathrm{mg} / 100 \mathrm{ml})$ and seven levels of $2.90 \mathrm{mmol} / 1(11.6 \mathrm{mg} / 100 \mathrm{ml})$ or more. The vast majority of cancers giving rise to hypercalcaemia are "overt" rather than "occult."

We have found immunoassayable PTH to be detectable in the serum of $25 \%$ of patients with hypercalcaemia of malignancy (table II) although this percentage varies with the assay used. While the presence of circulating immunoreactive PTH in a hypercalcaemic patient with malignancy (past or present) does not distinguish between hypercalcaemia of malignancy and hypercalcaemia of hyperparathyroidism the absence of detectable circulating PTH makes the co-existence of hyperparathyroidism extremely unlikely.

TABLE II-Serum PTH increases* in hypercalcaemia of malignancy

\begin{tabular}{|c|c|c|c|}
\hline \multicolumn{2}{|c|}{$\begin{array}{l}\text { Site of } \\
\text { primary malignancy }\end{array}$} & \multirow{2}{*}{$\begin{array}{c}\text { No with } \\
\text { serum calcium } \\
\begin{array}{c}\geqslant \cdot 70 \mathrm{mmol} / 1 \\
(10.8 \mathrm{mg} / 100 \mathrm{ml})\end{array} \\
16 \\
10 \\
6 \\
5 \\
5 \\
32 \\
\end{array}$} & \multirow{2}{*}{$\begin{array}{c}\begin{array}{c}\text { No with } \\
\text { raised* } \\
\text { serum PTH }\end{array} \\
5 \\
3 \\
0 \\
4 \\
1 \\
7\end{array}$} \\
\hline $\begin{array}{l}\text { Breast .. } \\
\text { Lung .. } \\
\text { Myeloma } \\
\text { Large bowel } \\
\text { Kidney .. } \\
\text { Other .. }\end{array}$ & $\begin{array}{ll}\cdots & \cdots \\
\cdots & \cdots \\
\cdots & \cdots \\
\cdots & \cdots \\
. & .\end{array}$ & & \\
\hline \multicolumn{2}{|r|}{ Total } & 74 & 20 \\
\hline \multicolumn{2}{|c|}{ Subtract multiple cancers } & 3 & 2 \\
\hline \multicolumn{2}{|c|}{ Grand total } & 71 & 18 \\
\hline
\end{tabular}

*Any detectable immunoreactive PTH is considered raised in hypercalcaemic patients.

In addition, even in patients with severe hypercalcaemia of malignancy we have never seen detectable PTH levels greater than three times the upper limit of normal, whereas patients with severe hypercalcaemia associated with primary hyperparathyroidism usually have PTH levels 10 or 15 times the upper limit of normal. ${ }^{7}$ Thus, in a patient with a serum calcium of $4 \cdot 25-4.5 \mathrm{mmol} / 1(17-18 \mathrm{mg} / 100 \mathrm{ml})$ and a serum PTH level only twice the upper limit of normal the diagnosis of hyperparathyroidism should be viewed with suspicion. Benson's ${ }^{18}$ method of comparing the ratio between the circulating intact molecule and the C-terminal fragments of PTH is not, at this stage, available for routine clinical use.

\section{Hypercalcaemia of hyperthyroidism}

Between $5-10 \%$ of patients with hyperthyroidism are hypercalcaemic. ${ }^{19}$ In most cases this biochemical abnormality is mild and requires no treatment apart from control of the underlying disease. Four out of six patients with hypercalcaemia of hyperthyroidism whom we have seen had undetectable serum PTH levels.

Case 2-A 58-year-old housewife was found to have a serum calcium of $2.95 \mathrm{mmol} / 1(11.8 \mathrm{mg} / 100 \mathrm{ml})$ during routine investigations for hyperthyroidism. The serum PTH was $1.4 \mu \mathrm{g} / \mathrm{l}$. It was decided to perform a neck exploration rather than to give ${ }^{131} \mathrm{I}$. A partial thyroidectomy and removal of a parathyroid adenoma were performed at the same operation.

Comment-While the diagnosis in cases like this will probably become evident if hypercalcaemia persists after medical or ${ }^{131} I$ treatment, the high PTH level made the diagnosis obvious and enabled us to plan surgical treatment early in the course of the disease.

\section{Surgical hypoparathyroidism}

Until the advent of PTH assays surgical hypoparathyroidism had to be defined solely on the basis of hypocalcaemia and hyperphosphataemia in the absence of other factors causing such biochemical changes. ${ }^{20}$ There is now an additional diagnostic criterion-an undetectable PTH level in the presence of hypocalcaemia. This criterion may be useful in decision making both early and late in the course of this disease.

We have seen two patients who were hypocalcaemic and tetanic, one four months and the other three years after operation but in whom immunoassayable serum PTH subsequently became detectable. Vitamin D treatment was discontinued in these patients and two years later both remained normocalcaemic. Similarly, if a patient develops tetany or hypocalcaemia in the immediate post-thyroidectomy period a detectable PTH level in peripheral blood should alert the clinician to the possibility that he may be dealing with a transient condition.

\section{Renal failure}

Serum immunoassayable PTH rises in a linear fashion with increasing nitrogenous retention (fig 3 ) reaching a mean of 10 times the upper limit of normal as the patients approach the end stage of their

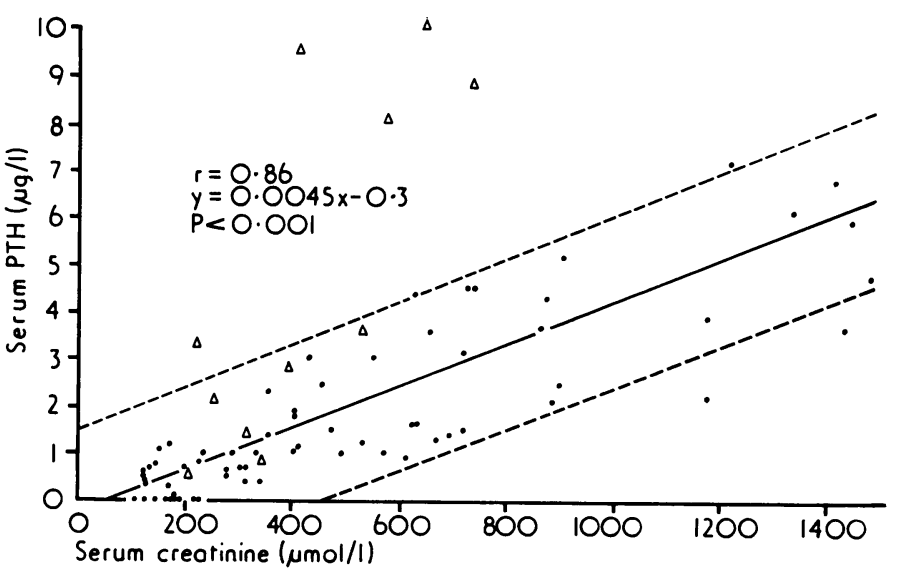

FIG 3-Linear correlation between serum creatinine and serum PTH in patients with chronic renal failure. Individual values are widely scattered about mean for any creatinine level. $=$ Patients without skeletal symptoms. $\triangle=$ Patients with skeletal symptoms. Regression was calculated on basis of patients without symptoms.

Conversion: SI to traditional units-Creatinine: $1 \mu \mathrm{mol} / 1 \approx 0.0113 \mathrm{mg}$ / $100 \mathrm{ml}$.

disease. A single haemodialysis makes little difference to PTH levels (fig 4), while chronic haemodialysis in most cases fails to change serum PTH levels from month to month. Thus some people have constantly high PTH levels throughout their dialysis while others, apparently on the same regimen, have much lower levels (fig 5). There is a 
reasonably good correlation between serum PTH levels and parathyroid osteopathy (table III). This information is useful in clinical practice.

Some patients with non-terminal renal failure have skeletal symptoms that dominate the clinical picture. ${ }^{21}$ Such patients (in whom skeletal biopsies usually show osteomalacia ${ }^{21}$ ) have higher immunoreactive PTH levels than patients with similar creatinine levels who do not have skeletal symptoms (fig 4). The presence of a disproportionately raised serum PTH in a patient with relatively mild renal failure should alert the physician to the possible presence of this syndrome.

TABLE III-Correlation between skeletal radiology, skeletal histology, and immunoreactive PTH in 15 patients on long-term haemodialysis

\begin{tabular}{c|c|c|c}
\hline $\begin{array}{c}\text { Case } \\
\text { No }\end{array}$ & $\begin{array}{c}\text { Radiological } \\
\text { changes of } \\
\text { hyperparathyroidism }\end{array}$ & $\begin{array}{c}\text { Histological } \\
\text { changes of } \\
\text { hyperparathyroidism } \\
(0-+++)\end{array}$ & $\begin{array}{c}\text { Serum } \\
\text { PTH } \\
(\mu \mathrm{g} / \mathrm{l})\end{array}$ \\
\hline 1 & Absent & 0 & 0 \\
2 & Present & +++ & $0 \cdot 4$ \\
3 & Absent & + & $0 \cdot 7$ \\
4 & Absent & + & $0 \cdot 8$ \\
5 & Absent & + & $0 \cdot 8$ \\
6 & Absent & + & $0 \cdot 8$ \\
7 & Absent & + & $0 \cdot 9$ \\
8 & Absent & ++ & $0 \cdot 9$ \\
9 & Absent & ++ & $1 \cdot 3$ \\
10 & Absent & +++ & $1 \cdot 7$ \\
12 & Absent & +++ & $2 \cdot 5$ \\
13 & Present & +++ & $2 \cdot 6$ \\
14 & Present & +++ & $4 \cdot 4$ \\
15 & Present & $4 \cdot 4$ \\
\hline
\end{tabular}

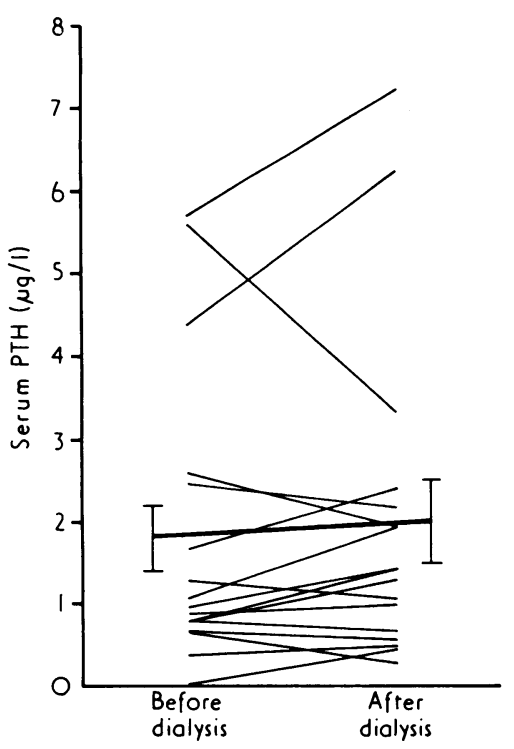

FIG 4-Serum immunoassayable PTH in 17 patients before and after single haemodialysis (against dialysate containing calcium $1.6 \mathrm{mmol} / 1(6.2 \mathrm{mg}$ $100 \mathrm{ml}$ ). While there were obvious alterations between pre- and postdialysis values, mean value (indicated by heavy bar) remained unchanged.

\section{Dialysis bone disease}

For reasons that are not entirely understood some patients receiving chronic dialysis, particularly at some centres, ${ }^{22}$ develop bony lesions consisting of osteomalacia, parathyroid osteopathy, or changes in bone volume in various combinations and permutations. ${ }^{23}$ Serial skeletal biopsies show an exacerbation of one or more of these lesions during maintenance haemodialysis in most patients (fig 5). Raised or rising PTH levels give some indication of the severity of parathyroid osteopathy (table III) without the need for serial bone biopsies and constitute an indication for an increase in the dialysis bath calcium ${ }^{24}$ or vitamin D administration, or both. Parathyroidectomy should be considered when these measures have failed. If a subtotal parathyroidectomy has been performed estimation of serum PTH levels gives some indication of the adequacy of the procedure and the likelihood of further surgery being needed.
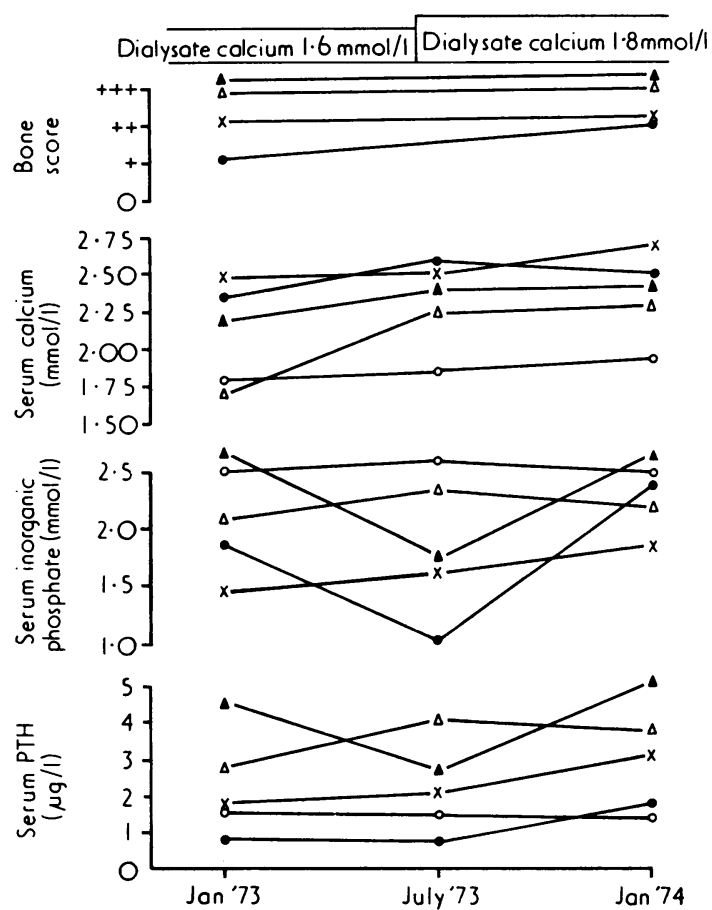

FIG 5-Pre-dialysis immunoassayable PTH, serum calcium, and serum inorganic phosphate in five patients on chronic haemodialysis followed over 12 months. Degree of parathyroid osteopathy ${ }^{7}$ in four of them is also shown. Change in dialysate calcium had no obvious influence on any values. Reason why parathyroid activity was greater in some patients than in others is unknown. One patient $(\triangle-\triangle)$ would have been subjected to neck exploration if she had not died of myocardial infarction in March 1974.

Conversion: SI to traditional units-Calcium: $1 \mathrm{mmol} / 1 \approx 4 \mathrm{mg} / 100 \mathrm{ml}$. Phosphate: $1 \mathrm{mmol} / \mathrm{l} \approx 3.1 \mathrm{mg} / 100 \mathrm{ml}$.

\section{Renal transplantation and "tertiary" hyperparathyroid- ism}

"Primary" hyperparathyroidism is said to be present when parathyroid hyperplasia and hypersecretion are noted in the absence of an identifiable stimulus. "Secondary" hyperparathyroidism is the name given to parathyroid hyperplasia and hypersecretion in the presence of what is believed to be a recognisable stimulus, provided the response is "appropriate." "Tertiary" hyperparathyroidism is said to be present when the parathyroid response to a given stimulus is "excessive" so that serum calcium, instead of being restored to normal levels, rises to abnormally high levels. St Goar, who coined the term, restricts it to an unusual condition that can be diagnosed only anatomically. ${ }^{25}$

After a successful renal transplantation serum PTH levels fall to about half the pretransplantation values in the first week after operation. ${ }^{26}$ They then continue to fall at a slower rate so that biochemical and histological evidence of hyperparathyroidism may still be found in allograft recipients some six years after successful renal transplantation in spite of good graft function. ${ }^{26} \mathrm{~A}$ few such individuals become temporarily or permanently hypercalcaemic in the face of falling serum PTH levels.

We have arbitrarily decided not to recommend parathyroidectomy in this condition unless there are skeletal symptoms or the serum calcium rises to $3.0 \mathrm{mmol} / 1(12 \mathrm{mg} / 100 \mathrm{ml})$ or above. The falling PTH levels have reinforced this decision though it may take many years follow up to determine whether this decision is correct. The patient discussed by Wilson $e t a^{25}$ would not have been subjected to neck exploration in our hospital.

\section{PTH measurements in blood from neck veins}

In addition to the effort involved and the potential morbidity there are two major drawbacks to the use of selective venous catheterisation as a diagnostic measure for localising parathyroid tumours: $(a)$ venous effluent from normal glands in euparathyroid subjects may show higher PTH concentrations than peripheral blood ${ }^{27}$; and the venous drainage of the neck is such that a "hot spot" in a given region (par- 
ticularly in the left innominate vein) does not necessarily imply a parathyroid lesion in the immediate vicinity. ${ }^{7}$ This applies particularly in patients who have previously undergone neck exploration. We currently believe that selective venous catheterisation followed by PTH assay has a high cost:benefit ratio and that this procedure should be used only rarely.

Case 3-A 48-year-old man, who had been admitted to a psychiatric institution because of irrational behaviour, was found to have a serum calcium concentration of $3.6 \mathrm{mmol} / 1(14.4 \mathrm{mg} / 100 \mathrm{ml})$. He became normocalcaemic after the administration of prednisone $60 \mathrm{mg} /$ day for 10 days, with a recurrence of hypercalcaemia when steroid medication was discontinued. After a fruitless search for non-parathyroid lesions believed to be responsible for his hypercalcaemia PTH assays were performed on peripheral blood samples and blood samples taken from the major neck veins. The results are shown in fig 6. Neck exploration was performed and a 3.1-g parathyroid adenoma was removed from behind the left upper pole of the thyroid.

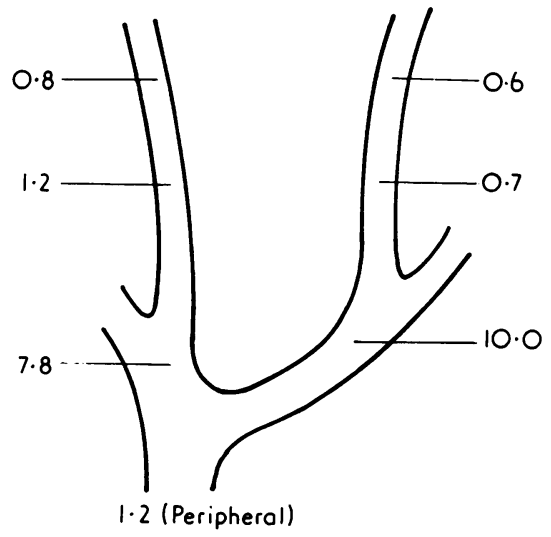

FIG 6-Case 3. PTH levels $(\mu \mathrm{g} / 1)$ in venous samples taken from various neck veins as indicated. At operation a parathyroid adenoma was found behind the left upper pole of the thyroid. Surgeon commented that a vein drained direct from adenoma into left innominate vein. A "gradient" similar to that shown here has been found in patients with upper mediastinal tumours.

Comment-As a localising exercise selective venous sampling was obviously useless in this case (fig 6). It was, however, useful in predicting that the patient had a PTH-secreting lesion somewhere in the neck (or possibly in the mediastinum) and not below the diaphragm. A similar use of this test was described by Heath et al, ${ }^{28}$ who showed high PTH levels in neck vein samples from patients with known malignant disease, thus establishing the presence of two conditions. In the two patients (cases 28 and 29) described by Tomlinson et $a^{29}$ the decision to explore the mediastinum rather than the neck was made on the basis of the absence of a gradient between the neck veins and the peripheral veins. While the absence of such a gradient makes the presence of a tumour in the neck unlikely the presence of a neck veinperipheral vein gradient may be caused by a mediastinal lesion.

\section{Procedures without influence on clinical decisions}

The molecular heterogeneity of circulating PTH has been thoroughly documented by several investigators. ${ }^{30} 31$ Unfortunately, the identification of this or that fragment does not seem to differentiate between hyperplasia, adenoma, or carcinoma of the parathyroids. There is evidence that ectopically produced PTH may have a molecular configuration that is different from that of the hormone produced by the parathyroid glands. This information has not yet reached the decisionmaking level. Also, recognition of peptide fragments does not help a surgeon decide whether to remove the main lesion he can identify and to leave the other glands alone or to follow Paloyan's practice $^{32}$ and to remove three and a half glands. Similarly, if there are syndromes of hypoparathyroidism characterised by the presence of a "warped" hormone ${ }^{33} 34$ the treatment of patients suffering from such syndromes is not at present influenced by their delineation.

The same lack of clinical usefulness applies to suppression tests. Apart from the ethical considerations of giving a hyper- calcaemic or a uraemic person a calcium infusion this type of procedure does not at present fit into any clinical flow chart. On the other hand, there is a distinct clinical potential for stimulation tests. If a patient is being treated with vitamin $D$ preparations for hypoparathyroidism and there is some doubt about the diagnosis artificially induced hypocalcaemia may show the presence of circulating PTH which was not present in the normocalcaemic state.

\section{Conclusion}

Tests, like treatments, go through cycles of over- and underuse. Provided the practising clinician orders a PTH assay in the appropriate conditions, this test is likely to lead to more decisions than many other endocrine immunoassays currently in use.

We thank the various doctors who referred patients for study. This work was supported by the National Health and Medical Research Council of Australia, New South Wales State Cancer Council, and the University of Sydney Cancer Research Fund. Mrs Susan Vedelago, Miss Margaret Wilkinson, and Miss Deborah Reynolds gave valuable technical and secretarial help. Dr Michael Parfitt (Detroit) reviewed the manuscript and made many helpful suggestions.

Requests for reprints should be addressed to $\mathrm{Dr} S$ Posen, Sydney Hospital, Box 1614, Sydney, NSW 2001, Australia.

\section{References}

${ }^{1}$ Reiss, E, and Canterbury, J M, Proceedings of the Society for Experimental Biology and Medicine, 1968, 128, 501.

2 Berson, S A, and Yalow, R S, American fournal of Medicine, 1971, 50, 623.

3 Arnaud, C D, Tsao, H S, and Littledike, T, fournal of Clinical Investigation, $1971,50,21$.

4 Potts, J T, et al, American fournal of Medicine, 1971, 50, 639.

5 Conaway, H H, and Anast, C S, fournal of Laboratory and Clinical Medicine, 1974, 93, 129.

6 Woo, J, and Singer, F R, Clinica Chimica Acta, 1974, 54, 161.

${ }^{7}$ Kleerekoper, M, et al, Clinical Chemistry, 1974, 20, 369.

${ }^{8}$ Lavan, J N, Neale, F C, and Posen, S, Medical fournal of Australia, 1971, 2,1049 .

9 White, $\mathrm{R} W$, et al, in Proceedings of the Renal Stone Research Symposium, ed A Hodgkinson, and B C E Nordin. London, Churchill, 1969.

10 Pak, C Y C, et al, fournal of Clinical Investigation, 1974, 54, 387.

11 Coe, F L, et al, fournal of Clinical Investigation, 1973, 52, 134.

12 Boonstra, C E, and Jackson, C E, Annals of Internal Medicine, 1963, 63, 468.

${ }^{13}$ McLellan, G, Baird, C W, and Melick, R, Medical fournal of Australia, $1968,2,354$.

14 Blackman, J E, et al, British Medical fournal, 1967, 2, 800.

15 Woodward, H Q, Cancer, 1953, 6, 1219.

16 Lafferty, F W, Medicine, 1966, 45, 247.

17 Bender, R A, and Hansen, H, Annals of Internal Medicine, 1974, 80, 205.

18 Benson, R C, et al, fournal of Clinical Investigation, 1974, 54, 175.

19 Baxter, J D, and Bondy, P K, Annals of Internal Medicine, 1966, 65, 429.

20 Ireland, A W, et al, Annals of Internal Medicine, 1968, 69, 81.

21 Ingham, J P, et al, Medical fournal of Australia, 1974, 1, 873.

${ }^{22}$ Pendras, J P, Archives of Internal Medicine, 1969, 124, 312.

23 Binswanger, U, et al, Nephron, 1973, 12, 1.

24 Fournier, A E, et al, fournal of Clinical Investigation, 1971, 50, 599.

25 Wilson, R E, and Castleman, B, New England fournal of Medicine, 1974, 290, 793.

${ }^{26}$ Kleerekoper, M, et al, British Medical fournal, 1975, 3, 680.

27 Shimkin, P M, and Powell, D, Annals of Internal Medicine, 1973, 78, 714.

${ }^{28}$ Heath, D A, Shimkin, P M, and Wolfe, D R, Fournal of Clinical Endocrinology and Metabolism, 1974, 38, 618 .

29 Tomlinson, S, et al, British fournal of Surgery, 1974, 61, 633.

${ }^{30}$ Silverman, R, and Yalow, R S, fournal of Clinical Investigation, 1973, 52, 1958.

31 Arnaud, C D, et al, American fournal of Medicine, 1974, 56, 785.

32 Paloyan, E, Lawrence, A M, and Straus, F H, Hyperparathyroidism. New York, Grune and Stratton, 1973.

${ }^{33}$ Nusynowitz, M L, and Klein, M H, American fournal of Medicine, 1973, $55,677$.

${ }^{34}$ Antony, G, Posen, S, and Beveridge, J, Proceedings of the Endocrine Society of Australia, 1975, 18, 4.

${ }^{35}$ Pratley, S K, Posen, S, and Reeve, T S, Medical fournal of Australia, 1973, 1, 421. 